\title{
Building-Related Symptoms among U.S. Office Workers and Risks Factors for Moisture and Contamination: Preliminary Analyses of U.S. EPA BASE Data
}

\author{
Mark J. Mendell and Myrna Cozen \\ Environmental Energy Technologies Division \\ Indoor Environment Department \\ Lawrence Berkeley National Laboratory \\ Berkeley, CA 94720
}

September 2002

This work was supported by the Indoor Environment Division, Office of Radiation and Indoor Air, Office of Air and Radiation of the U.S. Environmental Protection Agency through Interagency Agreement DW89939365-01-0 with the U.S. Department of Energy. This work was also supported by the assistant Secretary for Energy Efficiency and Renewable Energy, Building Technologies Program of the U.S. Department of Energy under contract DE-AC03-76SF00098. 


\title{
Building-Related Symptoms among U.S. Office Workers and Risks Factors for Moisture and Contamination: Preliminary Analyses of U.S. EPA BASE Data
}

\author{
Mark J. Mendell \\ Myrna Cozen
}

\begin{abstract}
Background: We assessed relationships between health symptoms in office workers and risk factors related to moisture and contamination, using data collected from a representative sample of U.S. office buildings in the U.S. EPA BASE study.

Methods: Analyses assessed associations between three types of weekly, workrelated symptoms - lower respiratory, mucous membrane, and neurologic - and risk factors for moisture or contamination in these office buildings. Multivariate logistic regression models were used to estimate the strength of associations for these risk factors as odds ratios (ORs) adjusted for personal-level potential confounding variables related to demographics, health, job, and workspace.

Results: A number of risk factors were associated (e.g., 95\% confidence limits excluded 1.0) significantly with small to moderate increases in one or more symptom outcomes. Significantly elevated ORs for mucous membrane symptoms were associated with the following risk factors: presence of humidification system in good condition versus none $(\mathrm{OR}=1.4)$; air handler inspection annually versus daily $(\mathrm{OR}=1.6)$; current water damage in the building $(\mathrm{OR}=1.2)$; and less than daily vacuuming in study space $(\mathrm{OR}=1.2)$. Significantly elevated $\mathrm{ORs}$ for lower respiratory symptoms were associated with: air handler inspection annually versus daily $(\mathrm{OR}=2.0)$; air handler inspection less than daily but at least semi-annually $(\mathrm{OR}=1.6)$; less than daily cleaning of offices (1.7); and less than daily vacuuming of the study space $(\mathrm{OR}=1.4)$. Only two statistically significant risk factors for neurologic symptoms were identified: presence of any humidification system versus none $(\mathrm{OR}=1.3)$; and less than daily vacuuming of the study space $(\mathrm{OR}=1.3)$. Dirty cooling coils, dirty or poorly draining drain pans, and standing water near outdoor air intakes, evaluated by inspection, were not identified as risk factors in these analyses, despite predictions based on previous findings elsewhere, except that very dirty cooling coils were associated with a nonsignificant increase in lower respiratory symptoms

Conclusions: These preliminary findings suggest that some factors that indicate risks for moisture or contamination in office buildings may have adverse effects on respiratory or neurologic health of office workers. More refined analyses are underway that will include these risk factors in simultaneous multivariate models along with additional risk factors that may be confounders, such as ventilation rate and indoor temperature. Future analyses will also use more refined metrics for both health outcomes and environmental risks, as well as assess risk in susceptible sub-groups.
\end{abstract}




\section{Background}

\section{History of building-related symptoms}

Episodes of nonspecific health complaints in indoor workplaces, not attributable to specific recognized disease or exposures, have been commonly reported in recent decades (Mendell 1993). Sometimes referred to as sick building syndrome (SBS), these episodes have involved widespread complaints of symptoms and discomfort, including mucous membrane irritation, nasal symptoms, skin irritation, headache, fatigue, and sometimes breathing problems. These symptoms are often reported to occur in the building and to diminish away from the building. The nonspecific symptoms involved in so-called SBS have generally not been associated with objective findings on clinical examination or abnormalities in laboratory tests (Kreiss 1989).

Although specific causal exposures for what we will here call nonspecific buildingrelated symptoms (BRS) have not yet been documented, research has identified a number of person-, job-, workplace-, and building-related risk factors for these symptoms (e.g., presence of air-conditioning systems, low ventilation rate, high temperature, dust, endotoxin,) (Mendell 1993; Gyntelberg et al. 1994; Teeuw et al. 1994).

In contrast to BRS, defined disease attributable to a specific exposure in a building is often referred to as building-related illness (BRI). Documented BRI in indoor, nonindustrial workplaces such as office buildings has been reported occasionally (Hodgson et al. 1987; Kreiss 1989; Hoffman et al. 1993; Seuri et al. 2000; Jarvis and Morey 2001). Most reported episodes have involved respiratory disease such as hypersensitivity pneumonitis or humidifier fever associated with microbiologic contamination of the indoor environment; e.g., Hodgson (1987). Although symptoms assessed in buildings, particularly lower respiratory symptoms, may ultimately be linked to such building-related illnesses, such links have not yet been established. Identifying specific causal exposures and related biologic mechanisms of response will be necessary to elucidate underlying illness. However, identification of building features and practices that increase risk of symptoms may allow early preventive actions.

Available evidence suggest that multiple biologic response mechanisms may ultimately be identified among non-specific BRS, presenting with overlapping sets of symptoms yet resulting from different single or combined indoor exposures. Researchers have often treated the multiple symptoms reported in buildings as a single syndrome (e.g., Burge (1987), although some researchers have considered sub-syndromes such as central nervous systems and mucous membrane irritation symptoms (Jaakkola and Miettinen 1995; Mendell et al. 1996). Few reports have considered lower respiratory symptoms, which have been the least commonly reported symptoms assessed in indoor environments (Ruotsalainen et al. 1995; Mendell et al. 1996; Sieber et al. 1996), although potentially indicative of serious health effects.

Much research in residential environments has associated moisture, mold, and related factors with upper and lower respiratory symptoms (Bornehag et al. 2001). Empirical 
evidence has long suggested that moisture and contamination in commercial and institutional buildings such as offices has been related to occupant health complaints. However, only recently have studies reported the association of risks related to moisture and contamination in non-industrial indoor environments with increased symptoms among workers (Ruotsalainen et al. 1995; Mendell et al. 1996; Sieber et al. 1996).

\section{Goals, hypotheses, and strategies of current analysis}

The primary goals of this analysis are: to identify moisture- and contaminant-related risk factors in buildings and ventilation systems for building-related symptoms among workers in representative US office buildings; to identify subgroups more susceptible to these risk factors; to identify improved metrics for the health outcomes related to these risks; and to replicate findings about these risk factors in a set of US office buildings investigated for indoor air quality complaints. We report here the results of initial analyses related to the first goal.

We hypothesized that certain features or practices in buildings, including in ventilation systems and in occupied spaces, increase the risk of moisture or contamination of surfaces, which in turn increase the risk of exposure for occupants to microorganisms or other toxins that may have irritant, toxic, or allergic effects. Therefore, we predicted statistical associations between specific features or practices in buildings and certain symptoms among occupants - lower respiratory, mucous membrane, and neurologic reported as relatively frequent and improving when away from the buildings. Although not assessed yet in the findings reported here, we also predicted that among identified microbiologic-related risks for lower respiratory symptoms, these risks should be stronger for building-related symptoms than for symptoms assessed without this restriction, for more stringently defined and severe symptom outcome definitions, and among the subset of previously diagnosed asthmatics.

We estimated relationships between building risk factors and health outcomes in multivariate regression models controlling for potential personal, job, workspace, and building risk factors, and for measured IEQ factors as feasible. Multiple logistic regression models were used to estimate adjusted odds ratios.

\section{Methods}

We used the BASE data set, collected between 1994-1998 by the U.S. EPA from 100 representative US office buildings, that includes a variety of information on both occupants and buildings. Descriptions of this study and the available data have been reported previously (Womble et al. 1996; Brightman et al. 1999). Briefly, the study selected a representative set of 100 office buildings from geographic regions throughout the U.S., and then randomly selected within each building a study space with at least 50 occupants, and with no more than two air handling units. Data was collected from questionnaires given to all occupants of each study space, from standardized inspections of the buildings and ventilation systems, and from standardized interviews conducted with facility managers. Data variables used in analyses here include information from the occupant questionnaires (on demographic, health, job, and workspace factors) and from 
the inspections and interviews. We selected data variables and checked, cleaned, modified, and combined them as needed for the present analyses.

We constructed a number of symptom-based health outcome definitions for our analyses, and required them to be temporally related to work. These included groups of symptoms representing various types of effects -- lower respiratory, mucous membrane, neurologic, allergic, and skin hypothesized to be potentially "building-related" - as well as a group of symptoms that might be experienced as work-related, but are hypothesized to be nonbuilding-related- the "control" symptoms. The analyses presented here include only the first three groups of symptoms. Later analyses will include the additional groups of symptoms, as well as outcome definitions requiring more and fewer symptoms, single symptoms, outcomes not restricted to work-related, outcomes reflecting reported frequency of symptoms, and various other symptom metrics to refine the risk relationships.

We identified existing variables and created summary metric variables for risks of moisture or contamination within the ventilation systems or within the buildings or occupied spaces (Table 1). Some were from observations and some from interviews with facility managers. Variables included presence of or condition of components in the ventilation system, presence of outside water, schedule of ventilation inspection, water damage indoors, and frequency of indoor cleaning procedures. From the existing data values, we combined values or variables as necessary to create variables suitable for assessing our hypotheses. The current analysis includes single variables. Future analyses will include indices of risk combining and weighting information from multiple risk variables.

This analysis included variables in all models to adjust for potential confounding by person-level variables, including demographic, health, job, and workspace factors. This analysis did not include variables related to other indoor exposures or other physical or geographic features of the buildings.

Multivariate modeling was performed using SAS version 8 (SAS Institute 2002). We first ran univariate frequencies for the risk factors of interest, showing the number of buildings and respondents for each level of each risk factor. Then, for each symptom outcome, we constructed initial logistic regression models to estimate partially adjusted odds ratios (ORs) for each of the risk factors; e.g., each model included a dependent term for one symptom outcome and independent terms for one risk factor and also for potential personal-level confounding variables related to demographics, health history, job, and workspace.

An odds ratio (OR) of 1.0 indicates no apparent relationship between the suspected risk factor and the prevalence of the health symptom. An OR exceeding 1.0 indicates an increased prevalence of symptoms in the population exposed to the risk factor and an OR less than 1.0 indicates a decreased prevalence of symptoms. The multivariate models used correct the odds ratios for potential confounding other factors related to both the risks of interest and the health outcomes being studied. 
Table 1. Moisture- and contaminant-related risk variables assessed in analyses of 100 U.S. office buildings, 1994-1998

\begin{tabular}{|c|c|c|c|}
\hline & & \multicolumn{2}{|c|}{ Type of Risk Factor } \\
\hline $\begin{array}{c}\text { Location of Risk } \\
\text { Factor }\end{array}$ & Risk Factor & Moisture & Contamination \\
\hline Ventilation system & $\begin{array}{l}\text { Condition of cooling coils } \\
\text { Condition of drain pans } \\
\text { Condition of air intake } \\
\text { Condition of filtration system } \\
\text { Intake near standing water } \\
\text { Frequency of air handler inspection }\end{array}$ & $\begin{array}{l}\mathrm{X} \\
\mathrm{X} \\
\mathrm{X} \\
\mathrm{X} \\
\mathrm{X}\end{array}$ & $\begin{array}{l}X \\
X \\
X \\
X \\
X \\
X\end{array}$ \\
\hline $\begin{array}{l}\text { Building or occupied } \\
\text { space }\end{array}$ & $\begin{array}{l}\text { Past water damage - building } \\
\text { Past water damage - space } \\
\text { Current water damage - building } \\
\text { Current water damage - space } \\
\text { Frequency of office cleaning - bldg } \\
\text { Frequency of vacuuming - building } \\
\text { Frequency of vacuuming - space } \\
\text { Frequency of wet mopping - bldg } \\
\text { Frequency of wet mopping -- space }\end{array}$ & $\begin{array}{l}X \\
X \\
X \\
X \\
\\
\\
X \\
X\end{array}$ & $\begin{array}{l}X \\
X \\
X \\
X \\
X \\
X \\
X \\
X \\
X\end{array}$ \\
\hline
\end{tabular}

\section{Results}

Table 2 shows the proportion of buildings, and also the proportions of respondents, at different levels of the risk variables assessed in this paper. Ninety-nine of 100 buildings studied had air-conditioning, so risks associated with air conditioning could not be assessed.

The proportions of respondents with each of the weekly work-related symptom outcomes analyzed here was as follows: mucous membrane, 29.4\%; lower respiratory, $7.9 \%$; and neurologic, $24.8 \%$.

Tables $3 \mathrm{a}$ and $3 \mathrm{~b}$ shows the odds ratios (ORs) and 95\% confidence intervals (CI) for the risks assessed, by outcome variable. These risks are adjusted for personal-level covariates but not for the other environmental risks.

Among the ventilation system-related risk factors (Table 3a), presence of a humidification system in any of the air handlers supplying a study space was associated with a small to moderate elevation of risk for all outcomes: for neurologic symptoms, OR (95\% confidence interval $(\mathrm{CI})=1.32$ (1.05-1.65), and for mucous membrane symptoms, OR $(95 \% \mathrm{CI})=1.23(0.99-1.53)$. When the humidification systems were further classified by condition (from inspection), the risk for humidifiers was, for two symptom outcomes, higher for humidifiers in poor condition than for those in good condition. For mucous membrane symptoms, the risk was highest for humidifiers in good condition: OR $(95 \% \mathrm{CI})=1.39$ (1.05-1.84). Inspection of air handlers less than daily was associated with a substantial and significant increase in lower respiratory symptoms, and inspection 
only annually was associated with a substantial and significant increase in mucous membrane symptoms. On the other hand, condition of the cooling coils, drain pans,

Table 2. Variables for risks of moisture or contamination in ventilation systems or buildings $($ Freq $=$ frequency)

\begin{tabular}{|c|c|c|}
\hline \multicolumn{3}{|c|}{ Ventilation System Factors } \\
\hline Risk Factor & $\begin{array}{l}\text { Number } \\
(\%) \text { of } \\
\text { buildings }\end{array}$ & $\begin{array}{l}\text { Number of } \\
\text { buildings } \\
\text { with } \\
\text { information }\end{array}$ \\
\hline $\begin{array}{l}\text { Presence of } \\
\text { humidification } \\
\text { yes, poor condition } \\
\text { yes, good condition } \\
\text { no }\end{array}$ & $\begin{array}{c}3 \\
7 \\
85\end{array}$ & 95 \\
\hline $\begin{array}{l}\text { Condition of coils } \\
3 \\
2 \\
1\end{array}$ & $\begin{array}{l}11 \\
35 \\
46\end{array}$ & 92 \\
\hline $\begin{array}{l}\text { Condition of drain pans } \\
3 \\
2 \\
1\end{array}$ & $\begin{array}{l}27 \\
35 \\
28\end{array}$ & 90 \\
\hline $\begin{array}{l}\text { Condition of air intake } \\
3 \\
2 \\
1\end{array}$ & $\begin{array}{l}10 \\
37 \\
50\end{array}$ & 97 \\
\hline $\begin{array}{l}\text { Condition of filtration } \\
\text { system } \\
3 \\
2 \\
1\end{array}$ & $\begin{array}{l}10 \\
34 \\
53\end{array}$ & 97 \\
\hline $\begin{array}{l}\text { Standing water near } \\
\text { intake of any } \\
\text { ventilation system } \\
\text { Yes } \\
\text { No }\end{array}$ & $\begin{array}{l}28 \\
72\end{array}$ & 100 \\
\hline $\begin{array}{l}\text { Frequency of system } \\
\text { inspection } \\
\text { Less than quarterly } \\
\text { Quarterly or semi-q } \\
\text { Biweekly to monthly } \\
\text { Daily }\end{array}$ & $\begin{array}{l}13 \\
30 \\
31 \\
14\end{array}$ & 88 \\
\hline
\end{tabular}

\begin{tabular}{|c|c|c|}
\hline \multicolumn{3}{|c|}{ Building or Occupied Space Factors } \\
\hline Risk Factor & $\begin{array}{l}\text { Number } \\
(\%) \text { of } \\
\text { buildings }\end{array}$ & $\begin{array}{c}\text { Number of } \\
\text { buildings } \\
\text { with } \\
\text { information }\end{array}$ \\
\hline $\begin{array}{l}\text { Water damage, past } \\
\text { (building) }\end{array}$ & 85 & 100 \\
\hline $\begin{array}{l}\text { Water damage, current } \\
\text { (building) }\end{array}$ & 43 & 100 \\
\hline $\begin{array}{l}\text { Water damage, past } \\
\text { (space) }\end{array}$ & 41 & 100 \\
\hline $\begin{array}{l}\text { Water damage, current } \\
\text { (space) }\end{array}$ & 20 & 97 \\
\hline $\begin{array}{l}\text { Frequency of office } \\
\text { cleaning (building): } \\
\text { As needed } \\
\text { Less than daily } \\
\text { Daily }\end{array}$ & $\begin{array}{c}3 \\
7 \\
89\end{array}$ & 99 \\
\hline $\begin{array}{l}\text { Frequency of floor } \\
\text { vacuuming (building): } \\
\text { As needed } \\
\text { Less than daily } \\
\text { Daily } \\
\end{array}$ & $\begin{array}{c}3 \\
18 \\
78 \\
\end{array}$ & 99 \\
\hline $\begin{array}{l}\text { Frequency of floor } \\
\text { vacuuming (space): } \\
\text { As needed } \\
\text { Less than daily } \\
\text { Daily }\end{array}$ & $\begin{array}{c}5 \\
19 \\
73\end{array}$ & 97 \\
\hline $\begin{array}{l}\text { Frequency of floor wet } \\
\text { mopping (building): } \\
\text { As needed } \\
\text { Less than daily } \\
\text { Daily }\end{array}$ & $\begin{array}{c}3 \\
11 \\
86 \\
\end{array}$ & 100 \\
\hline $\begin{array}{l}\text { Frequency of floor wet } \\
\text { mopping (space): } \\
\text { As needed/none } \\
\text { Less than daily } \\
\text { Daily }\end{array}$ & $\begin{array}{l}11 \\
11 \\
76 \\
\end{array}$ & 98 \\
\hline
\end{tabular}


outdoor air intakes, and filtration systems in the air handlers and standing water near outdoor air intake were not associated with changes in symptom outcomes, except that very dirty coils was associated with an OR of 1.34 for lower respiratory symptoms $(95 \%$ $\mathrm{CI}=0.86-2.10)$.

Among the building or occupied space factors (Table 3b), current water damage in the building was associated with small increases in mucous membrane $(\mathrm{OR}(95 \% \mathrm{CI})=1.20$ $(1.01-1.42)$ and lower respiratory symptoms $(\mathrm{OR}(95 \% \mathrm{CI})=1.26(0.94-1.68))$, relative to spaces without evident damage in the building. Current water damage evident in the study space was associated with smaller elevations, not statistically significant, in all three symptoms. Because water damage reported at the building-level did not always include water damage at the space level and vice-versa, we constructed an additional metric combining these separate observations and using a reference level of study spaces with no observed water damage at either the space or building level. Although changes between the smaller groups at these levels were not statistically significant, this metric found the lowest risks (ORs $=0.80-1.22)$ with water damage observed only in the space, intermediate risks (ORs $=1.00-1.25)$ with water damage observed only at the building level, and the highest risks (ORs $=1.26-1.33)$ where water damage was observed at both space and building levels.

General office cleaning in the building less than daily (between weekly and annually), relative to cleaning daily, was associated with a significant increase in lower respiratory symptoms $(\mathrm{OR}(95 \% \mathrm{CI})=1.72(1.12-2.63))$, but with little or no increase in neurologic or mucous membrane symptoms. (The small response category "performed as needed," which had few responses and did not specify a particular cleaning interval, was associated variously with risk or protection, almost never significantly, among the various cleaning and maintenance variables, and was not considered interpretable.) Vacuuming in the building less than daily, relative to vacuuming daily, was associated with significant increases in mucous membrane symptoms $(\mathrm{OR}(95 \% \mathrm{CI})=1.32(1.08$ $1.63)$ ), lower respiratory symptoms $(\mathrm{OR}(95 \% \mathrm{CI})=1.44(1.03-2.01))$, and neurologic symptoms $(\mathrm{OR}(95 \% \mathrm{CI})=1.27(1.02-1.58))$. Likewise, vacuuming in the study space less than daily was associated with significant increases in mucous membrane symptoms $(\mathrm{OR}(95 \% \mathrm{CI})=1.25(1.02-1.52))$, lower respiratory symptoms $(\mathrm{OR}(95 \% \mathrm{CI})=1.43$ $(1.04-1.98))$, and neurologic symptoms $(\mathrm{OR}(95 \% \mathrm{CI})=1.34(1.08-1.64))$.

In contrast, less than daily wet mopping in the building or the study space, compared to daily mopping, was not clearly associated with any outcome. Wet mopping in the building as needed (reported in three buildings), compared to daily mopping, was associated with a significantly decreased risk of mucous membrane symptoms (OR (95\% $\mathrm{CI})=0.55(0.33-0.91)$ ) 
Table 3a. Partially adjusted odds ratios ${ }^{1}$ (ORs) and $95 \%$ confidence intervals (CIs) for associations between symptoms among occupants and risks of moisture or contamination in ventilation systems, from separate multiple logistic regression models for each risk, in the EPA BASE data collected from U.S. office buildings, 1994-1998 ( $p=p$-value; $n=$ number of respondents in model)

\begin{tabular}{|c|c|c|c|c|c|c|c|c|c|c|c|c|}
\hline \multirow[t]{2}{*}{ Ventilation System Risk Factor } & \multicolumn{4}{|c|}{ Mucous Membrane Symptoms } & \multicolumn{4}{|c|}{ Lower Respiratory Symptoms } & \multicolumn{4}{|c|}{ Neurologic Symptoms } \\
\hline & $\mathrm{OR}^{2}$ & $95 \% \mathrm{CI}$ & $\mathrm{p}$ & $n$ & $\mathrm{OR}^{2}$ & $95 \% \mathrm{CI}$ & $\mathrm{p}$ & $n$ & $\mathrm{OR}^{2}$ & $95 \% \mathrm{CI}$ & $\mathrm{p}$ & $n$ \\
\hline $\begin{array}{l}\text { Presence of humidification system } \\
\text { No }\end{array}$ & $\begin{array}{l}1.23 \\
1.0 \\
\end{array}$ & $\begin{array}{l}0.99-1.53 \\
---\end{array}$ & $\begin{array}{l}0.06 \\
---\end{array}$ & 3012 & $\begin{array}{l}1.24 \\
1.0\end{array}$ & $0.87-1.77$ & $\begin{array}{l}0.23 \\
--- \\
\end{array}$ & 3012 & $\begin{array}{l}1.32 \\
1.0\end{array}$ & $\begin{array}{l}1.05-1.65 \\
---\end{array}$ & $\begin{array}{l}0.02 \\
---\end{array}$ & 3014 \\
\hline $\begin{array}{l}\text { Presence of humidification system } \\
\text { Yes, poor condition } \\
\text { Yes, good condition } \\
\text { No }\end{array}$ & $\begin{array}{l}1.22 \\
\mathbf{1 . 3 9} \\
1.0 \\
\end{array}$ & $\begin{array}{l}0.83-1.80 \\
1.05-1.84 \\
---\end{array}$ & $\begin{array}{l}0.31 \\
0.02 \\
--- \\
\end{array}$ & 2889 & $\begin{array}{l}1.30 \\
1.16 \\
1.0 \\
\end{array}$ & $\begin{array}{l}0.71-2.39 \\
0.74-1.84 \\
--- \\
\end{array}$ & $\begin{array}{l}0.39 \\
0.50 \\
--- \\
\end{array}$ & 2889 & $\begin{array}{l}1.44 \\
1.21 \\
1.0 \\
\end{array}$ & $\begin{array}{l}0.96-2.15 \\
0.90-1.62 \\
--- \\
\end{array}$ & $\begin{array}{l}0.08 \\
0.21 \\
--- \\
\end{array}$ & 2891 \\
\hline $\begin{array}{l}\text { Condition of AH coils } \\
\text { Very dirty } \\
\text { Somewhat dirty } \\
\text { Clean }\end{array}$ & $\begin{array}{l}1.02 \\
1.02 \\
1.0\end{array}$ & $\begin{array}{l}0.77-1.37 \\
0.84-1.23 \\
---\end{array}$ & $\begin{array}{l}0.87 \\
0.83 \\
--- \\
\end{array}$ & 2801 & $\begin{array}{l}1.340 .99 \\
1.0\end{array}$ & $\begin{array}{l}0.86-2.10 \\
0.71-1.37 \\
---\end{array}$ & $\begin{array}{l}0.19 \\
0.95 \\
---\end{array}$ & 2801 & $\begin{array}{l}1.09 \\
0.95 \\
1.0\end{array}$ & $\begin{array}{l}0.81-1.47 \\
0.78-1.17 \\
---\end{array}$ & $\begin{array}{l}0.56 \\
0.64 \\
---\end{array}$ & 2803 \\
\hline $\begin{array}{l}\text { Condition of AH } \\
\text { drain pans } \\
\text { Very dirty } \\
\text { Somewhat dirty } \\
\text { Clean } \\
\end{array}$ & $\begin{array}{l}1.09 \\
0.91 \\
1.0 \\
\end{array}$ & $\begin{array}{l}0.87-1.37 \\
0.73-1.12 \\
---\end{array}$ & $\begin{array}{l}0.44 \\
0.36 \\
--- \\
\end{array}$ & 2737 & $\begin{array}{l}1.02 \\
0.95 \\
1.0 \\
\end{array}$ & $\begin{array}{l}0.69-1.49 \\
0.67-1.49 \\
--- \\
\end{array}$ & $\begin{array}{l}0.94 \\
0.78 \\
---\end{array}$ & 2736 & $\begin{array}{l}0.91 \\
0.91 \\
1.0 \\
\end{array}$ & $\begin{array}{l}0.72-1.16 \\
0.73-1.14 \\
---\end{array}$ & $\begin{array}{l}0.45 \\
0.40 \\
--- \\
\end{array}$ & 2738 \\
\hline $\begin{array}{l}\text { Condition of } \mathrm{AH} \\
\text { air intake } \\
\text { Very dirty } \\
\text { Somewhat dirty } \\
\text { Clean } \\
\end{array}$ & $\begin{array}{l}1.01 \\
0.95 \\
1.0\end{array}$ & $\begin{array}{l}0.75-1.35 \\
0.79-1.14 \\
---\end{array}$ & $\begin{array}{l}0.95 \\
0.56 \\
---\end{array}$ & 2948 & $\begin{array}{l}1.15 \\
1.03 \\
1.0\end{array}$ & $\begin{array}{l}071-1.86 \\
0.76-1.41 \\
---\end{array}$ & $\begin{array}{l}0.57 \\
0.83 \\
---\end{array}$ & 2948 & $\begin{array}{l}0.84 \\
0.93 \\
1.0\end{array}$ & $\begin{array}{l}0.62-1.56 \\
0.77-1.14 \\
---\end{array}$ & $\begin{array}{l}0.29 \\
0.53 \\
---\end{array}$ & 2950 \\
\hline $\begin{array}{l}\text { Condition of AH } \\
\text { filtration system } \\
\text { Very old } \\
\text { Somewhat old } \\
\text { Good } \\
\end{array}$ & $\begin{array}{l}1.09 \\
1.08 \\
1.0 \\
\end{array}$ & $\begin{array}{l}0.78-1.53 \\
0.90-1.30 \\
---\end{array}$ & $\begin{array}{l}0.62 \\
0.41 \\
--- \\
\end{array}$ & 2948 & $\begin{array}{l}1.02 \\
1.15 \\
1.0 \\
\end{array}$ & $\begin{array}{l}0.57-1.82 \\
0.84-1.57 \\
---\end{array}$ & $\begin{array}{l}0.94 \\
0.38 \\
--- \\
\end{array}$ & 2948 & $\begin{array}{l}0.82 \\
1.04 \\
1.0 \\
\end{array}$ & $\begin{array}{l}0.56-1.19 \\
0.85-1.26 \\
---\end{array}$ & $\begin{array}{l}0.29 \\
0.71 \\
--- \\
\end{array}$ & 2950 \\
\hline $\begin{array}{l}\text { Standing water near } \\
\text { intake of any AH } \\
\text { no }\end{array}$ & $\begin{array}{l}1.13 \\
1.0\end{array}$ & $\begin{array}{l}0.94-1.36 \\
---\end{array}$ & $\begin{array}{l}0.18 \\
---\end{array}$ & 3012 & $\begin{array}{l}0.95 \\
1.0 \\
\end{array}$ & $\begin{array}{l}0.61-1.30 \\
---\end{array}$ & $\begin{array}{l}0.74 \\
--- \\
\end{array}$ & 3012 & $\begin{array}{l}1.04 \\
1.0\end{array}$ & $\begin{array}{l}0.86-1.27 \\
---\end{array}$ & $\begin{array}{l}0.68 \\
---\end{array}$ & 3014 \\
\hline $\begin{array}{l}\text { Frequency of AH inspection } \\
\text { As needed } \\
\text { Annually } \\
2 \text { weeks- } 6 \text { months } \\
\text { Daily }\end{array}$ & $\begin{array}{l}0.76 \\
\mathbf{1 . 6 4} \\
0.97 \\
1.0 \\
\end{array}$ & $\begin{array}{l}0.47-1.22 \\
1.07-2.53 \\
0.77-1.24 \\
---\end{array}$ & $\begin{array}{l}0.26 \\
0.02 \\
0.83 \\
--- \\
\end{array}$ & 2707 & $\begin{array}{l}1.80 \\
1.951 .61 \\
1.0\end{array}$ & $\begin{array}{l}0.85-3.81 \\
0.96-3.96 \\
1.01-2.56 \\
---\end{array}$ & $\begin{array}{l}0.12 \\
0.06 \\
0.04 \\
--- \\
\end{array}$ & 2707 & $\begin{array}{l}0.68 \\
1.140 .8 \\
2 \\
1.0 \\
\end{array}$ & $\begin{array}{l}0.41-1.13 \\
0.73-1.78 \\
0.64-1.06 \\
---\end{array}$ & $\begin{array}{l}0.14 \\
0.57 \\
0.12 \\
--- \\
\end{array}$ & 2708 \\
\hline
\end{tabular}

Each model contains one building or HVAC risk factor, adjusted for all of the following covariates from occupant questionnaires - gender, age, education, job category, smoking status, asthma diagnosis, mold allergy diagnosis, hay fever diagnosis, use of computers, use of photocopiers, hours per week at work, years in building, job satisfaction, job demand, job conflict, presence of carpet, distance from window, number of other workers in room.

${ }^{2}$ ORs with confidence limits excluding 1.0 are printed in bold type. 
Table 3b. Partially adjusted odds ratios ${ }^{1}$ (ORs) and $95 \%$ confidence intervals (CIs) for associations between symptoms among occupants and risks of moisture or contamination in buildings, from separate multiple logistic regression models for each risk, in the EPA BASE data collected from U.S.

office buildings, 1994-1998 ( $p=p$-value; $n=$ number of respondents in model)

\begin{tabular}{|c|c|c|c|c|c|c|c|c|c|c|c|c|}
\hline \multirow[t]{2}{*}{$\begin{array}{l}\text { Building or Occupied Space } \\
\text { Risk Factor }\end{array}$} & \multicolumn{4}{|c|}{ Mucous Membrane Symptoms } & \multicolumn{4}{|c|}{ Lower Respiratory Symptoms } & \multicolumn{4}{|c|}{ Neurologic Symptoms } \\
\hline & $\mathrm{OR}^{2}$ & $95 \% \mathrm{CI}$ & $\mathrm{p}$ & $n$ & $\mathrm{OR}^{2}$ & $95 \% \mathrm{CI}$ & $\mathrm{p}$ & $n$ & $\mathrm{OR}^{2}$ & $95 \% \mathrm{CI}$ & $\mathrm{p}$ & $n$ \\
\hline $\begin{array}{l}\text { Water damage, current } \\
\text { Building and space } \\
\text { Building only } \\
\text { Space only } \\
\text { None anywhere }\end{array}$ & $\begin{array}{l}1.291 .2 \\
1 \\
1.22 \\
1.0\end{array}$ & $\begin{array}{l}1.00-1.67 \\
0.99-1.47 \\
0.83-1.81 \\
---\end{array}$ & $\begin{array}{l}0.06 \\
0.06 \\
0.31 \\
---\end{array}$ & 2940 & $\begin{array}{l}1.33 \\
1.25 \\
0.88 \\
1.0\end{array}$ & $\begin{array}{l}0.86-2.05 \\
0.90-1.74 \\
0.40-1.92 \\
---\end{array}$ & $\begin{array}{l}0.20 \\
0.19 \\
0.74 \\
---\end{array}$ & 2940 & $\begin{array}{l}1.26 \\
1.00 \\
0.80 \\
1.0\end{array}$ & $\begin{array}{l}0.97-1.64 \\
0.81-1.23 \\
0.51-1.24 \\
---\end{array}$ & $\begin{array}{l}0.09 \\
1.00 \\
0.31 \\
---\end{array}$ & 2940 \\
\hline $\begin{array}{l}\text { Water damage, current } \\
\text { In building } \\
\text { None in building }\end{array}$ & $\begin{array}{l}\mathbf{1 . 2 0} \\
1.0\end{array}$ & $\begin{array}{l}1.01-1.42 \\
---\end{array}$ & $\begin{array}{l}0.04 \\
---\end{array}$ & 3012 & $\begin{array}{l}1.26 \\
1.0\end{array}$ & $\begin{array}{l}0.94-1.68 \\
---\end{array}$ & $\begin{array}{l}0.12 \\
---\end{array}$ & 3012 & $\begin{array}{l}1.09 \\
1.0\end{array}$ & $\begin{array}{l}0.91-1.30 \\
---\end{array}$ & $\begin{array}{l}0.36 \\
---\end{array}$ & 3014 \\
\hline $\begin{array}{l}\text { Water damage, current } \\
\text { In space } \\
\text { None in space }\end{array}$ & $\begin{array}{l}1.19 \\
1.0\end{array}$ & $\begin{array}{l}0.96-1.47 \\
---\end{array}$ & $\begin{array}{l}0.11 \\
---\end{array}$ & 2940 & $\begin{array}{l}1.12 \\
1.0\end{array}$ & $\begin{array}{l}0.77-1.62 \\
---\end{array}$ & $\begin{array}{l}0.56 \\
---\end{array}$ & 2940 & $\begin{array}{l}1.12 \\
1.0\end{array}$ & $\begin{array}{l}0.90-1.41 \\
---\end{array}$ & $\begin{array}{l}0.31 \\
---\end{array}$ & 2940 \\
\hline $\begin{array}{l}\text { Water damage, past } \\
\text { In building } \\
\text { None in building }\end{array}$ & $\begin{array}{l}1.11 \\
1.0\end{array}$ & $\begin{array}{l}0.88-1.4 \\
--- \\
\end{array}$ & $\begin{array}{l}0.37 \\
--- \\
\end{array}$ & 3012 & $\begin{array}{l}1.03 \\
1.0 \\
\end{array}$ & $\begin{array}{l}0.69-1.53 \\
---\end{array}$ & $\begin{array}{l}0.90 \\
---\end{array}$ & 3012 & $\begin{array}{l}1.05 \\
1.0 \\
\end{array}$ & $\begin{array}{l}0.82-1.34 \\
---\end{array}$ & $\begin{array}{l}0.70 \\
-- \\
\end{array}$ & 3014 \\
\hline $\begin{array}{l}\text { Water damage, past } \\
\text { In space } \\
\text { None in space }\end{array}$ & $\begin{array}{l}1.13 \\
1.0\end{array}$ & $\begin{array}{l}0.94-1.36 \\
---\end{array}$ & $\begin{array}{l}0.18 \\
---\end{array}$ & 3012 & $\begin{array}{l}1.07 \\
1.0\end{array}$ & $\begin{array}{l}0.78-1.46 \\
---\end{array}$ & $\begin{array}{l}0.67 \\
---\end{array}$ & 3012 & $\begin{array}{l}0.94 \\
1.0\end{array}$ & $\begin{array}{l}0.77-1.14 \\
--\end{array}$ & $\begin{array}{l}0.51 \\
---\end{array}$ & 3014 \\
\hline $\begin{array}{l}\text { Frequency of office } \\
\text { cleaning (building): } \\
\text { As needed } \\
\text { Less than daily } \\
\text { Daily }\end{array}$ & $\begin{array}{l}0.69 \\
0.95 \\
1.0\end{array}$ & $\begin{array}{l}0.30-1.56 \\
0.70-1.28 \\
---\end{array}$ & $\begin{array}{l}0.37 \\
0.74 \\
---\end{array}$ & 2997 & $\begin{array}{l}0.39 \\
\mathbf{1 . 7 2} \\
1.0\end{array}$ & $\begin{array}{l}0.05-2.93 \\
1.12-2.63 \\
---\end{array}$ & $\begin{array}{l}0.36 \\
0.01 \\
---\end{array}$ & 2997 & $\begin{array}{l}0.93 \\
1.10 \\
1.0\end{array}$ & $\begin{array}{l}0.42-2.04 \\
0.81-1.50 \\
---\end{array}$ & $\begin{array}{l}0.85 \\
0.54 \\
---\end{array}$ & 2999 \\
\hline $\begin{array}{l}\text { Frequency of floor } \\
\text { vacuuming (building): } \\
\text { As needed } \\
\text { Less than daily } \\
\text { Daily }\end{array}$ & $\begin{array}{l}0.91 \\
\mathbf{1 . 3 2} \\
1.0\end{array}$ & $\begin{array}{l}0.55-1.53 \\
1.08-1.63 \\
---\end{array}$ & $\begin{array}{l}0.73 \\
0.008 \\
---\end{array}$ & 2992 & $\begin{array}{l}0.46 \\
\mathbf{1 . 4 4} \\
1.0\end{array}$ & $\begin{array}{l}0.14-1.56 \\
1.03-2.01 \\
---\end{array}$ & $\begin{array}{l}0.22 \\
0.03 \\
---\end{array}$ & 2992 & $\begin{array}{l}1.11 \\
1.27 \\
1.0\end{array}$ & $\begin{array}{l}0.65-1.91 \\
1.02-1.58 \\
---\end{array}$ & $\begin{array}{l}0.69 \\
0.03 \\
---\end{array}$ & 2994 \\
\hline $\begin{array}{l}\text { Frequency of floor } \\
\text { vacuuming (space): } \\
\text { As needed } \\
\text { Less than daily } \\
\text { Daily }\end{array}$ & $\begin{array}{l}1.16 \\
\mathbf{1 . 2 5} \\
1.0\end{array}$ & $\begin{array}{l}0.76-1.77 \\
1.02-1.52 \\
---\end{array}$ & $\begin{array}{l}0.48 \\
0.03 \\
---\end{array}$ & 2947 & $\begin{array}{l}0.93 \\
\mathbf{1 . 4 3} \\
1.0\end{array}$ & $\begin{array}{l}0.43-2.04 \\
1.04-1.98 \\
---\end{array}$ & $\begin{array}{l}0.86 \\
0.03 \\
---\end{array}$ & 2947 & $\begin{array}{l}1.04 \\
\mathbf{1 . 3 4} \\
1.0\end{array}$ & $\begin{array}{l}0.65-1.65 \\
1.08-1.64 \\
---\end{array}$ & $\begin{array}{l}0.88 \\
0.006 \\
---\end{array}$ & 2949 \\
\hline $\begin{array}{l}\text { Frequency of floor wet } \\
\text { mopping (building): } \\
\text { As needed } \\
\text { Less than daily } \\
\text { Daily }\end{array}$ & $\begin{array}{l}\mathbf{0 . 5 5} \\
0.91 \\
1.0\end{array}$ & $\begin{array}{l}0.33-0.91 \\
0.67-1.24 \\
---\end{array}$ & $\begin{array}{l}0.02 \\
0.55 \\
---\end{array}$ & 3012 & $\begin{array}{l}0.89 \\
1.18 \\
1.0\end{array}$ & $\begin{array}{l}0.42-1.91 \\
0.69-2.00 \\
---\end{array}$ & $\begin{array}{l}0.77 \\
0.55 \\
---\end{array}$ & 3012 & $\begin{array}{l}0.93 \\
0.89 \\
1.0\end{array}$ & $\begin{array}{l}0.57-1.53 \\
0.64-1.24 \\
---\end{array}$ & $\begin{array}{l}0.78 \\
0.50 \\
---\end{array}$ & 3014 \\
\hline $\begin{array}{l}\text { Frequency of floor wet } \\
\text { mopping (space): } \\
\text { As needed or none } \\
\text { Less than daily } \\
\text { Daily }\end{array}$ & $\begin{array}{l}0.95 \\
0.85 \\
1.0\end{array}$ & $\begin{array}{l}0.73-1.25 \\
0.62-1.16 \\
---\end{array}$ & $\begin{array}{l}0.73 \\
0.31 \\
---\end{array}$ & 2967 & $\begin{array}{l}1.20 \\
1.15 \\
1.0\end{array}$ & $\begin{array}{l}0.79-1.84 \\
0.68-1.97 \\
---\end{array}$ & $\begin{array}{l}0.39 \\
0.60 \\
---\end{array}$ & 2967 & $\begin{array}{l}1.16 \\
0.87 \\
1.0\end{array}$ & $\begin{array}{l}0.88-1.52 \\
0.62-1.20 \\
---\end{array}$ & $\begin{array}{l}0.29 \\
0.40 \\
---\end{array}$ & 2969 \\
\hline
\end{tabular}




\section{Discussion}

Presence of humidification systems was associated with increased risk of neurologic symptoms. Despite expectations of increased risk, neither poorer condition of various ventilation system components nor standing water near air intakes were associated with symptom increases in these data. Infrequent inspection of the air handler, however, was associated with risk of symptoms. Water damage, as expected, was associated with increased risk, although small, for some symptoms. More frequent use of dry methods of space cleaning, particularly vacuuming, was associated with significant reduction in a number of work-related symptoms among office workers. Wet mopping, on the other hand was not protective.

These findings add support for some common beliefs related to health effects of buildings: that humidification systems, water damage, inadequately monitored ventilation systems, and inadequate office cleaning are related to increased risks of symptoms among occupants.

Mendell (1996) found frequent, work-related lower respiratory symptoms in California office workers to be associated with presence of air-conditioning, relative to naturally ventilated buildings, with OR $(95 \% \mathrm{CI})=4.0(1.1-15)$. The authors suggested that contaminants from poorly maintained or operated ventilation systems were a potential explanation for the findings. This analysis, which assessed the aspects of ventilation systems considered most likely to produce contaminants, does not provide substantial support for this explanation. Sieber (1996), in analyses of data from NIOSH Health Hazard Evaluations (HHEs) in 80 US office buildings, found strong association of lower respiratory symptoms with deficiencies in HVAC maintenance or design. In multivariate adjusted analyses of the same data, Mendell found strong association of lower respiratory symptoms with poor drainage from the condensate pans and debris in the outdoor air intakes with increased risk of work-related lower respiratory symptoms. Findings in the present analysis are not consistent with these previous findings.

The difference between the OR and 1.0 approximates the proportional increase or decrease in symptom prevalence, when overall prevalence of a symptom is less than approximately $20 \%$. For example, an OR of 1.3 indicates a $30 \%$ increase in prevalence. Because the prevalence of mucous membrane and neurologic symptom outcomes in these analyses are approximately 29 and 25\%, the difference between OR and 1.0 for these outcomes will slightly overestimate the true proportional change in prevalence.

This analysis included 87 statistical tests. Chance would predict p-values less than 0.05 for about four of these tests even in the absence of true associations. Because p-values of 13 tests were less than 0.05 , most of these observed associations are likely not to be the result of chance. 


\section{Limitations in this analysis}

The range of conditions in the representative buildings included in this analysis may not have been sufficiently broad to identify the risks associated with very badly maintained buildings. The above-mentioned NIOSH HHE study (Mendell et al. submitted), on the other hand, was conducted in buildings being investigated for indoor air quality complaints, and thus may have included more buildings at the higher levels of the risk factors common to both studies. For instance, the most poorly maintained air handlers in the NIOSH study may have been much more contaminated than the BASE buildings.

The metrics used for categorizing conditions of ventilation systems and spaces, based on inspections and questionnaires using imprecise categories, are subject to substantial error. Reports from inspections required considerable judgment by the inspectors. The responses of facility personnel regarding the frequency of their inspections and maintenance activities are subject to recall bias and intentional misreporting. Even highly standardized and accurate reporting based on visual inspection would be likely to correlate only roughly with underlying causal exposures. Thus, additional errors in these subjective metrics could have obscured actual associations of suspected risk factors with health symptoms.

\section{Implications}

If the associations found in these analyses were causal, this would suggest an increase in symptoms among the very large proportion of the U.S. workforce that is employed in indoor environments. Although increased symptoms at work are likely to diminish both the well-being and work performance of the office workers, the clinical significance of these increased symptoms is unknown. Of the variety of symptoms reported in buildings and assessed in building studies, the lower respiratory symptoms (sometimes called "asthma-like" or breathing symptoms) are relatively uncommon. For instance, typical prevalence in non-complaint buildings for frequent, work-related shortness of breath is 2$4 \%$, vs. $20-30 \%$ for irritated eyes). For this reason, breathing symptoms in buildings are often ignored, although they have in some cases been documented to indicate serious building-caused respiratory diseases such as asthma, hypersensitivity pneumonitis, or humidifier fever.

Because these findings are for relationships found within a representative set of large U.S. office buildings, these findings may be more generalizable than those from the NIOSH HHE study of office buildings being investigated for complaints.

\section{Future analyses}

In upcoming analyses, we will construct models with scales of risk that combine the risk factors assessed singly here. We will include metrics based on carbon dioxide as indicators of per-person ventilation rate. We will include other measured exposures as potential confounders (e.g., fine or coarse particle concentrations, volatile organic compounds, temperature, and microbiologic organisms or products). We will compare estimates from models using different outcome definitions (e.g., symptom outcomes that improve away from the building vs. unrestricted outcomes; outcome definitions of 
different groups or clusters of symptoms associated with specific risk factors; symptom clusters associated with risk factors in asthmatics vs. in non-asthmatics).

\section{Acknowledgements}

This work was supported by the Indoor Environments Division, Office of Radiation and Indoor Air, Office of Air and Radiation of the U.S. Environmental Protection Agency through interagency agreement DW89939365-01-0 with the U.S. Department of Energy. This work was also supported by the assistant Secretary for Energy Efficiency and Renewable Energy, Building Technologies Program of the U.S. Department of Energy under contract DE-AC03-76SF00098, and We thank Howard Brightman for assistance in working with the BASE data, Christine Erdmann for assistance in SAS programming, Maureen Lahiff for statistical consultation, and Michael Apte and William Fisk for their helpful review of the manuscript.

\section{References}

Bornehag, C. G., G. Blomquist, et al. (2001). "Dampness in buildings and health: Nordic interdisciplinary review of the scientific evidence on associations between exposure to "dampness" in buildings and health effects (NORDDAMP)." Indoor Air 11(2): 72-86.

Brightman, H. S., L. A. Wallace, et al. (1999). Comparing symptoms in Unites States office buildings. Indoor Air '99: Proceedings of the 8th International Conference on Indoor Air Quality and Climate, Edinburgh, Scotland, Construction Research Communications Ltd.

Burge, S., A. Hedge, et al. (1987). "Sick building syndrome: a study of 4373 office workers." Ann Occup Hyg 31(4A): 493-504.

Gyntelberg, F., P. Suadicani, et al. (1994). "Dust and the sick building syndrome." Indoor Air 4: 223-38.

Hodgson, M. J., P. R. Morey, et al. (1987). "An outbreak of recurrent acute and chronic hypersensitivity pneumonitis in office workers." Am J Epidemiol 125(4): 631-8.

Hoffman, R. E., R. C. Wood, et al. (1993). "Building-related asthma in Denver office workers." Am J Public Health 83(1): 89-93.

Jaakkola, J. J. and P. Miettinen (1995). "Type of ventilation system in office buildings and sick building syndrome." Am J Epidemiol 141(8): 755-65.

Jarvis, J. Q. and P. R. Morey (2001). "Allergic respiratory disease and fungal remediation in a building in a subtropical climate." Appl Occup Environ Hyg 16(3): 380-8.

Kreiss, K. (1989). "The epidemiology of building-related complaints and illness." Occup Med 4(4): 575-92.

Mendell, M. J. (1993). "Non-specific symptoms in office workers: A review and summary of the epidemiologic literature." Indoor Air 3: 227-36.

Mendell, M. J., W. J. Fisk, et al. (1996). "Elevated symptom prevalence associated with ventilation type in office buildings." Epidemiology 7(6): 583-9.

Mendell, M. J., G. N. Naco, et al. "Work-related respiratory symptoms in office workers: analyses of standarized data from NIOSH Health Hazard Evaluations (in preparation)." 
Ruotsalainen, R., N. Jaakkola, et al. (1995). "Dampness and molds in day-care centers as an occupational health problem." Int Arch Occup Environ Health 66(6): 369-74.

SAS Institute (2002). SAS Version 8. 2002.

Seuri, M., K. Husman, et al. (2000). "An outbreak of respiratory diseases among workers at a water-damaged building--a case report." Indoor Air 10(3): 138-45.

Sieber, W. K., L. T. Stayner, et al. (1996). "The National Institute for Occupational Safety and Health indoor environmental evaluation experience. Part Three: Associations between environmental factors and self-reported health conditions." Applied Occupational and Environmental Hygiene. 11(12): 1387-1392.

Teeuw, K. B., C. M. Vandenbroucke-Grauls, et al. (1994). "Airborne gram-negative bacteria and endotoxin in sick building syndrome. A study in Dutch governmental office buildings." Arch Intern Med 154(20): 2339-45.

Womble, S. E., E. L. Ronca, et al. (1996). Developing Baseline Information on Buildings and Indoor Air Quality (Base '95). IAQ 96/Paths to Better Building Environments/Health Symptoms in Building Occupants, Atlanta, American Society of Heating Refrigeration and Air-conditioning Engineers. 